\title{
Na canoa de Mia Couto: a poética da travessia em O outro pé da sereia
}

\author{
Prof. MSc. Amilton José Freire de Queiroz ${ }^{1}$
}

\begin{abstract}
The main agenda of this article supports up to examine the scope of the poetic passage in the novel The Other Foot Mermaid (2006), Mia Couto. To wander in this fruitful fictional landscape, the compasses are articulated theoretical and methodological stoned by Tania Franco Carvalhaland Silviano Santiago, Benjamin Abdala Júnior, Laura Cavalcante Padilha, Eneida Maria de Souza, Bernd Zillah, Zilda Maria Cury Ferreira, Daniel-Henri Pageaux, Édouard Glissant, Linda Hutcheon, Homi Bhabha and Edward Said. With the keys reading gestated by these intellectuals, it is expected to enter the gates of the novel miacoutiano, so to read it under the limbo themed ties of solidarity established around the construction of literary scenes grounded in narrative figuration of actors that modulate the frequency of the thought of the border, the rhizome, the wandering and networks. Strolling at the crossroads of this rhizome of solidarity, looked under the auspices of the poetics of the crossing, this work moves towards mapping pathways characters undress the cloisters root monolingual as teach Glissant (2011), to become wandering beings who sojourn in the opaque areas of the paradoxes of physical and symbolic violence attributed to (s) African (s). From reading these posts cross exchanges, exchanges, deviations, drift, fragmentation, hybridity and mestizaje, you want to design a babbling culminating uncharted passages and transport operated in intercultural plan textualities contemporary fiction. Given this, our gaze is anchored in the lesson to read and analyze a literary text is to know that he loosened the literary frontier, calling the frame of other fields of knowledge, as scores Aeneid Souza. Thus, to close with the invaluable metaphor Tania Carvalhaland seeks to track the meetings at the crossing (1991), considering the meetings contribute, ultimately, to investigate ways of openness to the Other in the scenes rhizomatic cartography, border and wandering spelled onstage Letter Mia Couto.
\end{abstract}

Keywords: Bodies, Africa, Wandering, Cartography, Literature.

Resumo: A pauta principal deste artigo ampara-se no escopo de examinar a poética da travessia no romance O Outro Pé da Sereia (2006), de Mia Couto. Para perambular nessa frutuosa paisagem ficcional, serão articuladas as bús- 
solas teórico-metodológicas lapidadas por Tania Franco Carvalhal, Silviano Santiago, Benjamim Abdala Júnior, Laura Cavalcante Padilha, Eneida Maria de Souza, Zilá Bernd, Maria Zilda Ferreira Cury, Daniel Henri-Pageaux, Édouard Glissant, Linda Hutcheon, Homi Bhabha e Edward Said. Com as chaves de leitura gestadas por esses intelectuais, espera-se entrar pelas portas do romance miacoutiano, de tal forma a lê-lo sob o limbo temático dos laços de solidariedade estabelecidos em torno da construção de cenas literárias alicerçadas na figuração de atores narrativos que modulam na frequência do pensamento da fronteira, do rizoma, da errância e das redes. Passeando na encruzilhada desse rizoma de solidariedade, olhado sob os auspícios da poética da travessia, o presente trabalho movimenta-se rumo ao mapeamento de percursos de personagens que se despem das clausuras da raiz monolíngue, como ensina Glissant (2011), para tornam-se seres errantes que peregrinam nas zonas opacas dos paradoxos da violência física e simbólica imputada à(s) África(s). A partir da leitura transversal desses lugares de trocas, intercâmbios, desvios, deriva, fragmentação, hibridismo e mestiçagem, quer-se projetar um balbucio que culmine por mapear as passagens e os transportes interculturais operados no plano das textualidades ficcionais contemporâneas. Em face disso, nosso olhar ancora-se na lição de que ler e analisar um texto literário é saber que ele esgarça a fronteira literária, convocando a moldura de outros campos do saber, conforme pontua Eneida Souza. Destarte, para fechar com a prestimosa metáfora de Tania Carvalhal, busca-se rastrear os encontros na travessia (1991), haja vista os encontros contribuírem, em última instância, para investigar os modos de abertura ao Outro na cartografia das cenas rizomáticas, fronteiriças e errantes grafadas no palco da letra de Mia Couto.

Palavras-chave: Corpos, África, Errância, Cartografia, Literatura.

\section{Bordejando travessias}

\section{"Quem elegeu a busca, não pode recusar a travessia". Guimarães Rosa}

Apresentado no I Seminário Nacional quando foi o Pós-colonial? Diálogos, Perspectivas e Limiares nas Literaturas Luso-africanas, no painel Literaturas Luso-africanas em diálogo, o presente texto tem como ponto de partida a conjugação das vozes rascantes de dois intelectuais preocupados em esmiuçar os trânsitos entre os imaginários do Oriente e Ocidente. Elas demarcam os limites do debate que o leitor encontrará ao longo deste colóquio argumentativo: a leitura dos mapas da poética da travessia no romance miacoutiano. A primeira reflexão é a do martinicano Édouard Glissant, com a afirmação de que "a poética não é uma arte do sonho ou da ilusão, mas sim uma maneira de conceber a si mesmo, de conceber a relação consigo mesmo e com o outro e expressá-la. Toda poética constitui uma rede (GLISSANT, 2005, p. 159).

A segunda impostação insere-se na fresta do olhar do francês Daniel-Henri Pageaux, ao focalizar que o comparatista tem a "vocação de estabelecer relações, de refletir sobre tudo que interliga e diferencia as literaturas e culturas entre si, mas também sobre 
os contatos, as permutas e os diálogos”(PAGEAUX, 2011, p. 23).

O deslocamento no dueto das palavras de Glissant e Pageaux contribuiu para rascunhar o título Na canoa de Mia Couto - a poética da travessia em OPS. Escavando as sementes discursivas espalhadas na trama da letra miacoutiana, pretende-se chegar à cartografia de cenas ficcionais despidas da homília do discurso etnocêntrico através da focalização heteróclita de alteridades flutuantes radicadas na mutabilidade de distintas latitudes do globo terrestre.

Ao se grafar a expressão Na canoa de Mia Couto, tem-se em mira traduzir os desdobramentos da instigante metáfora "O livro é uma canoa" (COUTO, 2006, p. 238). Posicionado nesse lugar desprovido de amarras, logo, catalizador de experiências várias, o olhar comparatista articulado para entrar nas fendas dessa canoa passeia, inicialmente, pelas malhas da palavra de Glissant e Pageaux, convocando, também, outros estudiosos para fecundar interpretações sobre os pactos ficcionais miacoutianos.

\section{Por uma poética da travessia em Mia Couto}

De partida, impõe-se de cabal importância declarar o foco desta segunda parte do capítulo: levantar os principais eixos de sustentação da prática literária de Mia Couto, dialogando com sua fortuna crítica para lançar as bases de uma poética da travessia na prosa de ficção miacoutiana.

Antes de entrar na vereda da fortuna crítica, é preciso pinçar, rapidamente, algumas palavras sobre a trajetória intelectual miacoutiana. De fato, o desempenho das funções de poeta, biólogo, jornalista e ficcionista dão a Mia Couto a chave para flanar, entrelaçando, pelas malhas de cinco gêneros discursivos - a saber: o poema, o conto, a crônica, o ensaio e o romance.

primeiro flagra as margens das palavras de Raiz do Orvalho (1983). O segundo comporta Vozes Anoitecidas (1986), Cada homem é uma raça (1990), Estórias Abensonhadas (1994), Contos do nascer da terra (1997), Na Berma de nenhuma estrada (1999) e Fio das missangas (2003). O terceiro explora as paisagens de Cronicando (1998). O quarto sedimenta-se nas instigantes chaves críticas de Passatempos (2005), E se Obama fosse africano (2009). O quinto âmbito textual - não mesmo importante - atravessa os labirintos de romances como Terra sonâmbula ${ }^{2}$ (1992), A varanda do frangipani ${ }^{3}$ (1996), Vinte e Zinco (1999), O último vôo do flamingo 4 (2000), Um rio chamado tempo, uma casa chamada terra $^{5}$ (2002), O outro pé da sereia ${ }^{6}$ (2006), Venenos de Deus, remédios do Diabo (2008) e Antes do nascer do mundo (2009) e A confissão da leoa (2012).

Do manejo com vários gêneros discursivos, autor moçambicano retira o alimento temático e formal para enlaçar as facetas paradoxais de várias alteridades heteroculturais, interculturais e transculturais, potencializando o jogo tradutório das relações ou interações textuais como peças de um mosaico, em suas constantes mobilidades, configurando, nessas travessias, os seus agenciamentos históricos, sociais e culturais (HOISEL, 2004, p. 151).

Destarte, atravessar e transitar são palavras-chave para compreender o sustentáculo do fazer intelectual miacoutiano, sobretudo se levada em consideração a prerrogativa de que seus textos quebram as fronteiras dos discursos monolíticos, conforme ele mesmo

2 TS.

$3 \mathrm{VF}$.

4 UVF.

5 RCTCHT.

6 OPS. 
aponta nas entrevistas que concede a pesquisadores da literatura de seu país, bem como nas intervenções feitas nos eventos de que participa como convidado, a exemplo do texto Os sete sapatos sujos, rio de imagens de onde se pescam as indicadoras palavras:

Moçambique não precisa apenas caminhar. Necessita de descobrir o próprio caminho num tempo enevoado e num mundo sem rumo. A bússola dos outros não serve, o mapa dos outros não ajuda. Necessitamos de inventar os nossos pontos cardeais. Interessa-nos um passado que não esteja carregado de preconceitos, interessa-nos o futuro que não nos venha como uma receita financeira. (COUTO, 2011, p. 44)

Para desvendar as “muitas raízes da nação que está por ser construída”, o autor entra no universo do romance não apenas para caminhar, ao contrário, tem em mira descobrir o ritmo do próprio passo dentro dos bosques do mundo marcado pelas idiossincrasias de sua paisagem cultural. Construir bússolas - quer dizer, rabiscar nas páginas dos romances - assim como dos contos, crônicas, ensaios, poemas, artigos e ensaios - roteiros da viagem que se equilibram na corda banda do contato entre culturas, (re)configurando, por conseguinte, o traçado do mapa das travessias, de si e do outro, no imaginário moçambicano.

No embaralhar do "tempo enevoado" - repleto de simultaneidades e contradições -, outras agulhas narrativas representacionais assinalam os pontos de opacidade nas brechas dos mosaicos da cultura africana, cadenciando "mais e mais o orgulho em serem quem são: moçambicanos construtores de um tempo e de um lugar onde nascemos todos os dias [...] Porque a verdade é uma: antes vale estar descalço do que tropeçar com os sapatos dos outros" (COUTO, 2011, p.47). Ao deixar nus os pés para sentir o chão moçambicano, Mia Couto perambula pelas frestas do passado para sonhar um futuro cavado pelos laços de solidariedade entre atores culturais cujos traumas servem de matéria-prima para traçar os contornos de:

Obras literárias, em especial as mais recentes, que problematizam, tematizando, a importância das vertentes das culturas e poéticas nos seus países. Isso acontece, com particular vivência, na literatura angolana e na literatura moçambicana. No caso dessa última, onde predomina a publicação do conto em desfavor do romance, a obra de Mia Couto tem manifestado uma conflitualidade dialógica na tematização das tradições se seu confronto com a modernidade. (LEITE, 2003, p. 37)

Da encruzilhada desse mosaico em aberto, a narrativa miacoutiana potencializa os paradoxos da modernidade (COMPAGNON 2010), alçando vôos rumo à tessitura de uma poética da relação energizada pela premissa de que o rizoma identitário moçambicano se prolonga em direção ao outro. Sendo assim, ao catar as estampas do imaginário da partilha, Mia Couto edifica personagens que andam a esmo por uma gama variada de regiões, continentes e mares. Dissecado em sua profundidade crítica, o modo miacoutiano de manejar esses lugares de passagem no plano ficcional coloca em estado de potência a lição de Édouard Glissant:

Acabaram os antigos rastros dos romances que começam num dado lugar, seguem movimentos inelutáveis e terminam numa espécie de fatalidade retórica. O que há de apaixonante no romance atual é que ele pode partir de todas as direções: ele percorre o mundo (2005, p. 151)

Recolhendo o grão da voz do intelectual martinicano, aponta-se, aqui, que o autor de $E$ se Obama fosse africano produz romances dedicados a pensar o mundo a partir do 
lugar que habita sem deixar, entretanto, de imaginar a totalidade-mundo, alimentando a representação literária de uma raiz desmultiplicada que se espraia pelo arquipélago do pensamento de que:

Enquanto todas as culturas do mundo não tiverem concebido que não é necessário aniquilar, erradicar uma outra cultura para afirmar-se a si mesmo, várias culturas estarão ameaçadas. Enquanto não tivermos aceito essa idéia, não apenas através do conceito, mas graças ao imaginário das humanidades - de que a totalidade-mundo é um rizoma no qual todos têm necessidade de todos, é evidente que culturas estarão ameaçadas. Não será nem através da força, nem através do conceito que protegeremos essas culturas, mas através do imaginário da totalidade-mundo, isto é, através da necessidade vivida do seguinte: todas as culturas têm necessidade de todas as culturas. (GLISSANT, 2005, p. 156).

(Des)costurando os sentidos das partidas, (v)idas e retornos de personagens que transitam por uma paisagem babélica, Mia Couto arremessa seu leitor diante de cenas narrativas radicadas na terra moçambicana, conduzindo-os aos diálogos com a totalidade-mundo dos imaginários orientais e ocidentais. Nas entrelinhas dessa estratégia, observa-se que ele se divorcia dos pactos escriturais levantados em torno do aniquilamento e da erradicação do diálogo entre culturas, cartografando, assim, os vestígios da memória dos "Condenados da terra" africana (FANON, 2008). Ademais, a escolha do romance, gênero de origem européia, como meio para energizar a dimensão das raízes de sua nação aponta para uma interlocução, tensa, porém necessária, com o signo alheio, diria Silviano Santiago. Tudo isso fica mais claro quando se penetra no território da análise de Maria Nazareth Soares Fonseca:

Nas narrativas de Mia Couto, chama atenção o motivo comum que atravessa sua escrita: a profunda crise econômica e cultural que acompanha o cotidiano da sociedade moçambicana, durante e depois da guerra civil, ou seja, após a independência nacional. Suas obras problematizam a instabilidade na qual está mergulhado o povo moçambicano, a concepção em todos os níveis de poder, as injustiças como conseqüência de um racismo étnico, a sobrevivência perante o estrangeiro, a perplexidade face às rápidas mudanças sociais, o desrespeito pelos valores tradicionais, a despersonalização e a miséria. De maneira geral, nas obras de Mia Couto, os motivos afloram de histórias algo insólitas. O insólito é acompanhado por episódios satíricos, que imprimem dimensões hilariantes às histórias (FONSECA, 2002, p. 45)

Deitado no berço do texto Panorama das literaturas africanas de língua portuguesa, o enunciado linguístico da pesquisadora da PUC-MG escava e apresenta algumas das pedras angulares: espaços, tempos, misérias, oralidade, escrita, estrangeiro, guerra e insólito. Por tal via, o palco da letra do escritor em foco nasce de uma conflitualidade dialógica de representações da imagem de si e do outro, urdida com a tradução dos percursos e performances de atores narrativos mergulhados na zona limítrofe das mutações do olhar transversal. Se Fonseca dá uma visão panorâmica do processo criativo miacoutiano, Ana Mafalda Leite, ampliando-o, conduz o debate para dentro das trilhas de Terra Sonâmbula, ao realçar:

Esse romance tem como pano de fundo a guerra civil que assolou o país até 1992. É uma narrativa que se reproduz em outras histórias. Organizada a partir de uma história matriz, a de um velho e uma criança abandonados junto a um carro incendiado no meio de uma estrada, alterna essa história uma outra, a do personagem Kindzu, 
que vem escrita nuns cadernos descobertos pela criança no interior do automóvel. Cada uma das histórias, a encaixada e a englobante, alternam, capítulo a capítulo, em unidades narrativas isoladas, que se encaixam ainda em outras histórias menores, mas que sempre se complementam através dos protagonistas, que se ouvem e se contam. (LEITE, 2012, p.223)

Edificada sobre os escombros da guerra civil, as cenas de TS exumam as fendas de um mundo traumático onde Muindinha e Tuhair negam-se a ficar paralisados no tempo e no espaço, pondo-se, ambos, a atravessar as fronteiras de seus imaginários através do contato com as histórias de Kindzu, encontradas dentro de um baú e que servem de alimento simbólico para sonhar com outros percursos para suas vidas completamente estilhaçadas.

É assim que as duas histórias - a dos deslocamentos da criança e do velho; e a viagem de Kindzu - misturam terras e sonhos para pontificar o percurso de vidas que descamam os véus do centro que começa dar lugar às margens, quando a universalização totalizante começa a desconstruir a si mesma, a complexidade das contradições que existem dentro das convenções [...] começam a ficar visíveis, seguindo a dianteira de Linda Hutcheon.

Expandindo mais esse raio de análise, a história encaixada e a englobante, de que fala Ana Leite, enlaçadas à cancha reflexiva da professora de Literatura Comparada na Universidade de Toronto, podem ser tidas como ferramenta composicional para indicar, no plano da arte literária, de que maneira se verifica o processo diluição dos centros em direção às margens. Isto é, em lugar de tecer enredos lineares para os quais concorrem à chegada a um único horizonte de expectativa, Mia Couto, em TS, garatuja uma série de histórias entrecortadas, séries de percursos e de trajetos, deixando aflorar uma prática discursiva calcada na tradução dos signos da diferença cultural moçambicana. Ao fim e ao cabo, essa postura escritural pode ser interfaceada à ligadura crítica de Édouard Glissant:

O escritor necessita pensar o mundo, mas não valendo-se de um pensamento informativo. Precisa fazê-lo através de um pensamento que pode ser intuitivo e tomar formas completamente específicas que partem de um lugar. Não vivemos no ar, não vivemos nas nuvens em volta da terra, vivemos em lugares. É preciso partir de um lugar e imaginar a totalidade-mundo. Esse lugar - que é incontornável - não deve ser um território a partir do qual olha-se o vizinho por cima de uma fronteira absolutamente fechada, e imbuído do desejo surdo de ir ao espaço do outro para impor-lhes as próprias idéias ou as próprias pulsões. (GLISSANT, 2005, p. 156)

Mantendo as fronteiras da letra abertas, para ouvir os balbucios de uma terra que vagueia pelo imaginário do leitor, a literatura de Mia Couto parte de uma busca constante de expressar os contornos de uma poética da viagem pautada na maneira de conceber a si mesmo, de conceber a relação consigo mesmo e com o outro e expressá-la. Toda poética constitui uma rede (GLISSANT, 2005, 159). Da incursão pela esfera textual de Introdução à poética da Diversidade, resultou a proposta de rastrear a poética da travessia em TS, principalmente depois de ouvir a voz do ficcionista descendente de portugueses:

Nós precisávamos desse Brasil como quem carece de um sonho que nunca antes soubéramos ter. Podia ser um Brasil tipificado e mistificado, mas era um espaço mágico onde nós renascíamos criadores de histórias e produtores de felicidade. Descobrimos essa nação no momento histórico em que nos faltava ser nação. Brasil - tão cheio de África, tão cheio da nossa língua e da nossa religiosidade - nos entregava essa margem que nos faltava para sermos rio (COUTO, 2011, p. 65). 
Aceitas tais coordenadas, identifica-se que olhares narrativos miacoutianos viajam pelas fronteiras do Atlântico e Índico, estabelecendo uma rede de diálogo com a cultura e literatura brasileira. A caminhada pelo "espaço mágico" fomenta o encontro com outra margem cultural, solidificando a constituição de "um rizoma, um campo, um tecido, uma trama de valores diferentes que se entrechocam e entrecruzam” (GLISSANT, 2005, p. 160).

Arremessadas nessa maré do contato entre imaginários, as paisagens textuais miacoutianas fisgam o movimento da partilha rascunhado no balançar e fraturar dos tentáculos da monovocalidade do lugar para testificar os liames e as conexões das tramas dos entrecruzamentos culturais nascidos entre Moçambique e Brasil - lugares de passagem cujas margens do rio se encontram para pactuar do mosaico da poética da travessia, deixando marcas e sopros da experiência tradutória do escritor que viaja por territórios sobrepostos e entrelaça histórias (SAID, 2005, p. 34).

Seja através das viagens que realiza no campo simbólico dos textos de Guimarães Rosa, Rachel de Queiroz, Manoel Bandeira, Jorge Amado, Adélia Prado, dentre outros, seja no plano físico de suas constantes vindas ao Brasil - para proferir Conferências e participar de Simpósios, Colóquios, Lançamentos de livros - Mia Couto carrega dentro de si as paisagens do "discurso de outrem" (BAKHTIN, 2006), sem deixar de tingir suas páginas dos códigos de pertença à cultura moçambicana e gingando-os com os de outras latitudes. Essa encenação da viagem/travessia pelo território do outro, na leitura de Laura Cavalcante Padilha:

Recupera lugares de diferença, pelos quais a alteridade encontra formas de projetarse imaginariamente, metonimizando-se em rios, ilhas, florestas, aldeias, savanas, montanhas, etc. Edifica-se assim, uma espécie de construção de uma identidade que poderíamos chamar pós-colonial e que, segundo Boaventura de Sousa Santos, se plasma nas 'margens das representações e através de um movimento que vai das margens para o centro'. E concluamos com ele: é um espaço em que é 'construída e negociada a diferença cultural' (PADILHA, 2009, p. 133).

Espaço de negociação cultural, TS diz mais do trânsito do que especificidades do lugar. Seus roteiros de passagem distanciam-se dos pântanos da raiz única em direção à raiz desmultiplicada, abrindo as portas da ficção para que as identidades andarilhas rasuram os lacres do olhar unívoco e tricotem outros pontos do novelo na narrativa das fraturas do sentido profundo dos entrecruzamentos culturais (FONSECA, 2009, p. 149). Mais uma vez, traz-se o sotaque de Laura Padilha, pois o texto literário miacoutiano é um espaço onde:

Essas novas negociações de sentido justificam o convite para que se viaje pelos caminhos que as culturas locais e imperiais ainda insistem em rasurar ou silenciar. $\mathrm{Ou}$ seja: aqueles que por onde circulam os povos pastoris, os dos quimbos e das lavras, os aldeões distantes, os das ancestrais machambas, os das florestas e beira-rios, os caçadores, os ilhéus e tantos outros, sempre no jogo "impalpável” que os religa ao mundo dos mortos que, aliás, não estão mortos, mas continuam a viver tudo o que existe na natureza (PADILHA, 2009, p.134)

As viagens pelo imaginário de alteridades voláteis, portanto, despidas da ameaça da homogeneidade global, articulam, na esfera estética, redes transfronteiriças que esgarçam os sentidos definitivos, armando teias discursivas cujos pontos de interação convidam o leitor a garimpar as formas do silêncio (ORLAND, 2008) sedimentadas na tradução da tópica das migrações culturais. A questão fica mais bem esboçada no argumento de Cury \& Fonseca: 
Já em Terra Sonâmbula, algumas constantes se configuram: uma escrita transgressora, o diálogo com o universo da oralidade, a palavra escrita ocupando papel de mediação e conservação das tradições e rituais das falas. Num mundo que se fragmenta, palco de guerras e deslocamentos, descaracterizações, a palavra escrita assume-se como local privilegiado de conservação e reinvenção da memória. Além disso, ela, escrita, se converte na possibilidade de retomada do espaço de pertença, de um espaço em que o homem possa se reconhecer (CURY \& FONSECA, 2008, p 25).

Dos muitos traçados críticos evocados pelas professoras da UFMG e PUC-MG, será aquecida a fornalha do debate de três pontos: a mediação, deslocamentos e espaço de pertença. Essa tríade temática aponta para a consolidação de uma poética da travessia, já que, partindo de uma sugestão de um deslocamento que adquire um sentido estético, o universo literário miacoutiano arma a representação de um mundo fragmentado - ou melhor - dilacerado pelos impropérios da guerra. Dessa forma, os seres de linguagem de Mia Couto deambulam pelo terreno de suas identidades e sondam os monumentos da barbárie (BENJAMIM, 1987, p.226) para reinventar-se no trato de suas memórias através da focalização de outros percursos de pertencimento.

Para lograr êxito nessa empreitada, Mia Couto aposta suas fichas narrativas no jogo literário da poética da travessia, cartografando as mutabilidades da experiência tradutória de cenas traumáticas da vida. Ou para ir-se às fendas do olhar de Michel de Certeau, o escritor moçambicano deixa resplandecer o sentido de que a vida entretém e desloca, ela suja, quebra e refaz, ela cria novas configurações de seres e de objetos, através de práticas cotidianas dos vivos, sempre semelhantes e diferentes (CERTEAU, 2011, p. 207). Outrossim, o estudo das novas configurações dos seres e objetos convoca novos jogadores para participar da partida representacional de $T S$, que, de acordo com Ana Mafalda Leite:

Pode-se considerar uma narrativa de viagens, as viagens escritas de Kindzu e as do velho e da criança, através dos relatos de Kindzu. As duas narrativas acabam confluindo, as personagens da história primeira começam viver os acontecimentos da segunda, as paisagens a misturar-se magicamente, e, no final, o romance termina unindo-as os sonhos à realidade. Quando digo que é o romance é uma narrativa de viagens, confiro-lhes o sentido iniciático de aprendizagem, conhecimento e descoberta. Por que se viaja em Terra Sonâmbula? Quem viaja? (LEITE, 2012, p. 224).

No romance em tela, o entrelaçar de vidas, espaços, culturas e tempos sinaliza para a urgência em se puxar os véus não apenas dos rastros do passado, mas também navegar no mar de novos gestos, às vezes sonhadores, que embaralham os percursos (ABDALA JUNIOR, 2003). Noutros termos, os percursos embaralhados - os de Tuahir e Muindinga, conectados aos de Kindzu - desbotam as tinturas e texturas da memória, pondo em posições equânimes os caminhos trilhados pelas personagens. A saber, todos os atores narrativos viajam dentro de si, via contato com o outro, alinhavando excessos, restos e encontros produtivos numa camada narrativa corroída pelo deslizar entre temporalidades que, ao invés de cercear, libertam os participantes das abotoadoras do imaginário de suas próprias fronteiras discursivas e estéticas. Por sua vez, essas últimas se abrem em direção ao rasurar, quebrar e diluir dos papados da trama da letra africana, passando a conjugar versões conflitantes das trocas e permutas com outras geografias culturais.

Como se pode constatar, o transpassar e o ligar de espacialidades - ruas, barcos, savanas, carros, rios, lojas, dentre outras mais - aciona o botão temático da travessia, via de acesso usada para apreender, conhecer e apresentar outros pactos do trânsito no imaginário 
moçambicano, tendo em conta folhear o álbum da tradição e modernidade para apanhar sementes no pasto das topografias ${ }^{7}$ da cultura moçambicana. Em seu desdobramento final, percebe-se que elas não estão de costas viradas para o cenário das tensões, antes, sim, escapelam as rotas da travessia enquanto uma ferramenta singular processo criativo miacoutiano. Fazendo um balanço do que foi dito até aqui, percebe-se que, em TS:

A viagem é da própria terra que procura encontrar-se, sonâmbula, perdida, a viagem de um país que a guerra fratricida ocupou lês a lês. A ausência de espaço seguro e de bússola percorre as personagens e suas ações. Deparamos, na primeira narrativa, com uma criança, desmemoriada e sem identidade, e um velho desaprendido da vida; a segunda, o jovem Kindzu quer tornar-se um guerreiro para lutar pela paz. Assistimos a um cotejo de personagens desesperançadas de tudo: no entanto, através de cada pequena viagem acontece uma nova história, uma iniciação. As diversas histórias que pontuam as viagens são essencialmente aprendizagem e fábula moralizante (LEITE, 2012, p. 224)

Viajar, portanto, é um verbo sine qua non para viandar pelas duzentas e quatro páginas de $T S$. Por elas, o leitor se perde e se encontra diante da impostação da voz de dois narradores: um que deambula pelas paisagens da terceira pessoa do discurso e o outro que passeia pelas zonas da primeira. Já pelos dois trajetos, encontra-se rascunhado um quadro multifacetado que topografa a penetração do outro (Kindzu), via olhar solidário, no território das agruras vividas por Muindinga e Tuahir, focalizados através da caminhada tradutória do narrador de terceira pessoa. Sendo assim, as fronteiras do narrar são rompidas através de uma amálgama de trajetórias que denunciam traços de outros mundos face às permutações de memórias que vasculham os tetos do discurso da linearidade pedagógica para urdir zonas ide travessia nas teias do mosaico da cultura moçambicana.

$\mathrm{O}$ enfoque do transbordamento das fronteiras no plano ficcional fica mais consistente no contato direto com a afirmação miacoutiana: "Um escritor é um viajante de identidades, um contrabandista de almas. Não escritor que não partilhe dessa condição: uma criatura de fronteira, alguém que vive junto à janela que se abre para territórios da interioridade" (COUTO, 2005, p. 45). Se o escritor é um viajante de identidades - quer dizer: transita entre mundos de linguagem para fecundar sinais da pertença a um lugar, assim como para identificar a estranheza que habita dentro de si mesmo, Mia Couto, explorando sua posição fronteiriça, tece "seres errantes que avançam e também viajam nas páginas dos cadernos de Kindzu que abrem as histórias da terra, seus mitos e suas maravilhas" (CURY \& FONSECA, 2008. p. 124).

Com as palavras dessas duas grandes investigadoras das literaturas africanas de língua portuguesa dá-se uma pausa na fortuna crítica sobre Mia Couto, porém se avança rumo à demonstração da poética da travessia no romance $O S P$.

\section{A poética da travessia em OPS}

"No início, viajávamos porque líamos e escutávamos, deambulando em barcos de papel, em asas feitas de vozes antigas. Hoje, viajamos para sermos escritos, para sermos palavras de um texto maior que é a nossa própria vida".

Mia Couto

7 CURY, M. Z. F. (Org.); ÁVILA, M. (Org.); Ravetti, G. (Org.). Topografias da cultura: representação, espaço e memória. 1. ed. Belo Horizonte: Editora UFMG, 2009. 
"Sobrevivemos porque fomos eternos errantes, caçadores dos acasos, visitantes de lugares que ainda estavam por nascer".

Mia Couto

"Ler sinais da paisagem, escutar silêncios, dominar linguagens e partilhar códigos".

Mia Couto

No ciclo de conferências proferidas na Universidade de Harverd, no Estado de Massachussets, especialmente na que trata da Exatidão - Italo Calvino presta um culto à potencialidade do jogo da palavra literária, apontando, de início, a seguinte ponderação:

\begin{abstract}
Por que me vem a necessidade de defender valores que a muitos parecerão simplesmente óbvios? Creio que meu primeiro impulso decorra de uma hipersensibilidade ou alergia pessoal: a linguagem me parece sempre usada de modo aproximativo, casual, descuidado, e isso me causa intolerável repúdio. Que não vejam nessa reação minha um sinal de intolerância para com o próximo: sinto um repúdio ainda maior ainda quando me ouço a mim mesmo. Por isso procuro falar o mínimo possível, e se prefiro escrever é que, escrevendo, posso emendar cada frase tantas vezes quanto ache necessário para chegar, não digo a me sentir satisfeito com minhas palavras, mas pelo menos a eliminar as razões de insatisfação de que mo posso dar conta. A literatura - quero dizer, aquela que responde a essas exigências - é a Terra Prometida em que a linguagem se torna aquilo que na verdade deveria ser (CALVINO, 1990, p. 72).
\end{abstract}

O autor italiano levanta uma questão preliminar que é substantiva: a literatura como um lugar em constante devir que permite aos leitores perderem-se e encontrarem-se nas fronteiras da Terra Prometida. Por outras palavras, o mundo posto de pé pelos contistas, ficcionistas, cronistas e poetas realinha temporalidades/espacialidades, entrelaçando-os para traduzir cenas permeadas pela exatidão das imagens e linguagens de seus textos. Nesse passo, outra passagem digna de menção é o esclarecimento do processo de escrita do também autor de Por que ler os clássicos (2004):

Às vezes procuro concentrar-me na história que gostaria de escrever e me dou conta de que aquilo que me interessa é uma outra coisa diferente, ou seja, mas tudo o que fica excluído daquilo que deveria escrever: a relação entre esse argumento determinado e todas as suas variantes e alternativas possíveis, todos acontecimentos que o tempo e o espaço possam conter. É uma obsessão devorante, destruidora, suficiente para me bloquear. Para combatê-la, procuro limitar o campo do que pretendo dizer, depois dividi-lo em campos ainda mais limitados, depois subdividir também estes, assim por diante. Uma outra vertigem então se apodera de mim, a do detalhe do detalhe, vejo-me tragado pelo infinitesimal, pelo infinitamente mínimo, como antes me dispersava no infinitamente (CALVINO, 1990, p. 82-83).

Transpondo o raciocínio de Calvino para esse trabalho, o campo de atuação delimitado para transitar criticamente ampara-se na literatura de Mia Couto - escritor africano cuja escrita literária conjuga o apetite por representar a deambulação dos corpos, bem como a inclinação para revisitar as paisagens da cultura dos "fora do lugar", "dos sem teto". Sem fugir do enfrentamento com as visões fantasmagóricas e exóticas, Couto projeta cenários textuais que fornecem perspectivas de leitura para o rastreamento das interconexões, das zonas de liminaridade e das disfoniais culturais tão prementes na vida dos moçambicanos.

Flagrante de todo esse cabedal de entrecruzamentos culturais, o fazer literário de Mia Couto, conforme se postou na abertura deste tópico, absorve as nuances do ser errante, 
isto é, ignora ainda onde seus pés o levarão (BERND, 2011). Mais ainda, assume a figura de um "eterno caçador" para visitar "lugares que ainda estavam por nascer". Em síntese, está-se diante de um escritor que mapeia as travessias, as errâncias e os nomadismos, encarando, portanto, a ficção como um lugar de possibilidade para reconstruir, ou mesmo recriar, novas bases, a história da imigração (CURY, 2006).

A vertente de análise de Maria Zilda Ferreira Cury ganha mais força quando aproximada ao posicionamento do também orquestrador de Venenos de Deus, remédios do Diabo (2008) - o de que "Ler sinais da paisagem, escutar silêncios, dominar linguagens é partilhar códigos". Noutras palavras, dimensionando as pedras angulares da ótica binária, o texto coutiano ressemantiza os (des) encontros entre história, memória e literatura. Circunstanciado entre esse triunvirato de mobilidades, o projeto de radiografia dos silêncios, das lembranças e dos esquecimentos guardados na prateleira textual da ex-colônia de Portugal é, efetivamente, uma das linhas de força que sustentam o mundo de linguagem miacoutiano.

Isto posto, urge sublinhar que o texto literário selecionado para observar a poética da travessia dos imaginários da diferença cultural, pensada na mesma direção de Homi Bhabha (2011), será a narrativa OPS, publicada, no Brasil, em 2006. Neste país tropical, a obra do também biólogo tem passeado pelo território das dissertações e teses de muitos Programas de Pós-Graduação.

Destarte, pode-se falar de uma migração do texto miacoutiano para a bacia cultural tupiniquim, ampliando o espectro das pesquisas comparatistas sobre as instâncias do "próprio e o alheio", consoante ponderaria Tania Franco Carvalhal (2003). Ou como tem defendido mais recentemente o pesquisador Benjamim Abdala Junior (2004) - a necessidade de se trabalhar no eixo relacional de um "comparativismo de cunho solidário" que esmiúcem as tangências.

Por tais vias, o ethos comparatista se expande e coopera para o mapeamento das zonas de contato entre regiões e continentes culturais, não mais sob as lentes de uma lupa teórica que apaga as heterogeneidades linguísticas, políticas, históricas, mas que ultrapassa as cercanias das fronteiras nacionais para discutir as relações recíprocas/assimetrias em torno dos pactos de visibilidade das margens, dos entre-lugares e o apetite pela errância nas paisagens culturais contemporâneas.

Viajando no território do imaginário cambiante, e sem um porto seguro para lançar a âncora de seu barco de papel, o autor do também importante Pensatempos revisita a praia dos discursos etnocêntricos para destroná-los de seus altares celebratórios do exotismo e rasurá-los, a tal ponto de transformá-los em imagens e palavras atravessadas de ambiguidades cuja potência semântica encontra-se em constante movimento de idas e vindas. Desse círculo paralelo traçado em esfera, o ficcionista em foco vasculha os templos da memória do passado para traduzir alguns traços da linha do presente, projetando, por conseguinte, cenários cujo desenho do futuro se constrói na elaboração de mapas literários que apresentam coordenadas do intercâmbio das vozes de imigrantes misturadas à algaravia de vozes moçambicanas.

Contextualizadas tais questões, entra-se nos bosques da ficção de $O P S$, visualizado na direção de Umberto Eco (2006). Esse lugar ficcional tem uma dimensão de 19 capítulos, distribuídos entre 331 páginas. O enredo gira em torno da partida de Mwadia Malunga, de Antigamente, rumo à sua terra natal - Vila Longe, respectivamente os espaços onde sem desenrolam as ações líricas, dramáticas e traumáticas da narrativa. Provenientes de variadas ascendências culturais - africanas, indianas, negras, brasileiras, moçambicanas, 


\section{Conexão Letras}

americanas - as 21 personagens que transitam por esses dois mundos de papel são guiadas por um narrador de terceira pessoa, o qual viaja entre duas temporalidades - uma inscrita no século XVI e outra no século XX.

Entrando propriamente no campo da narrativa $O P S$, seus dois primeiros capítulos apresentam-se como exemplares para pontuar os desdobramentos da temporalidade trabalhada nos idos de dezembro de 2002 (COUTO, 2006, p.9). Inicialmente, as personagens que transitam nesse labirinto temporal são o burriqueiro Zero Madzero, a viajante Mwadia Malunga e o curandeiro Lázaro Vivo. Esses três tempos de memória são as pontes discursivas que interligam os diálogos entre silêncio, oralidade e escrita. Assim vista, a prática de escrita de Couto revisita, propositalmente, a presença portuguesa com um olhar que não é tingido pelo sentimento da repulsa ou revolta, apontando para conformação de uma poética da travessia que faculta o trânsito entre as sendas da cultura do outro, esgarçando as fronteiras do narrar através do diálogo com "outros tempos saturados de agora".

O que ele deseja é, em última instância, saber os caminhos pelos quais os "dominadores" foram, ao cabo da história, modificados pela essência africana. Fazendo um balanço, pode-se chegar ao denominador comum de que, em $O S P$, a figuração da cultura portuguesa renasce africana ou descobre-se isolada em meio a uma cultura que lhe é completamente estranha.

Habitante da janela da história do contato dos imaginários, Mia Couto viaja entre várias identidades, vertendo para dentro de seu texto ficcional a entrada de personagens que enredam marcas multiculturais do "outro", colocando-nos diante de uma estranheza identitária que é, simultaneamente, estranheza de nós mesmos (KRISTEVA, 1998). Com isso, vêm à tona espaços, línguas e vidas estranhados, geografias estrangeiras vazadas na paisagem de textos que, mesmo falando sobre tópicas nacionais, realizam-no de maneira distanciada de uma feição autocentrada ou desinteressada das culturas estrangeiras (CURY, 2006).

O resultado desse procedimento de escrita é a montagem da poética da travessia. Nesse vagar pelo lugar de outrem, as personagens miacoutianas são marcadamente desterritorializadas, deslocadas de seu lugar familiar e com suas subjetividades sem repouso. Um exemplo da fuga do território natal pode ser visualizado na trajetória de Mwadia Malunga - nascida em Vila Longe e do qual parte rumo a Antigamente, cidade invisível $^{8}$ existente só no campo da memória dela e do marido Zero. Como um ser cuja subjetividade balança entre vários signos culturais, Malunga revela a prevalência dos intercâmbios espaciais, articulando fragmentos de paisagens, costumes e estilos de vida, além de pactuar espaços e aproximar diferenças sobre a tessitura da instabilidade da terra de adoção.

Igualmente, o percurso de Mwadia forja-se sob o ritmo dos deslocamentos entre a tendência do enraizamento e desenraizamento do jogo incessante da memória migrante dos intercâmbios das mobilidades linguísticas, históricas e culturais. Tal ambiência visualiza-se na própria envergadura do nome Mwadia - "que quer dizer canoa em si-nhungwé". Homenagem aos barquinhos que povoam os rios e os sonhos" (COUTO, 2006, p.19). A poética da travessia instaura-se no próprio percurso de Mwadia, pois ela se volta ao constante vagar simbólico da margem cultural africana, puxando alguns retalhos da memória moçambicana para misturá-los ao percurso de outros imaginários.

Tecida na dianteira de espaços móveis, logo, sem porto de ancoragem seguro, a corporeidade de Mwadia, qual esponja, absorve diferentes gotículas de identidades que,

8 CALVINO, Italo. As cidades invisíveis. Companhia das Letras, São Paulo, 2004.

9 Si-nhungwé: língua falada no Noroeste de Tete, Moçambique. Por vezes, grafada como shi-nhungué, cinyungué ou si-snyungwé, conforme aparece o registro explicativo na página 19 do romance OPS. 
misturadas, esmiúçam as potencialidades do quadro multifacetado das diferenças culturais, pulverizando ainda o exercício da transumância, a tal ponto de não respeitar as fronteiras nacionais na busca de novos horizontes onde seja possível intersectar experiências entre geografias errantes que se interpenetram mutuamente. Despido da pretensão de endossar o olhar da monovocalidade das origens, o itinerário polivalente de Mwadia testemunha a potencialidade de signos e vestígios efêmeros que são apagados muito facilmente. Nesse passo, o pensador Homi K. Bhabha recomenda:

O estudo da literatura mundial poderia ser o estudo do modo pelo qual as culturas se reconhecem através de suas projeções de alteridade. Talvez agora possamos sugerir que as histórias transnacionais de migrantes, colonizados ou refugiados políticos essas condições de fronteira e divisas - possam ser o terreno da literatura mundial, em lugar da transmissão de tradições nacionais, antes o tema central da literatura mundial (BHABHA, 1998, p.38).

A linha de trabalho proposta por Bhabha aponta a urgência em se traduzir as várias camadas culturais das produções literárias, abrindo rotas de leitura para "tentar apreender totalmente e assumir a responsabilidade pelos passados não ditos, não representados que assombram o presente histórico" (BHABHA, 1998, p. 34). Trocando em miúdos, o intelectual indo-britânico pauta seu debate na perspectiva de fazer vir à tona o passado escondido debaixo do tapete das narrações que ocultaram/ocultam os interditos, as tensões e as resistências solapadas dos arquivos da memória do presente histórico. Necessário se faz, de acordo com ele, percorrer, novamente, os labirintos dos textos que potencializam as imagens do contato entre "nós" e os "outros", com o intuito de ressemantizar as bifurcações divergentes do trânsito de uma cultura a outra.

É por meio do rastreamento e redimensionamento das bases do jogo discursivo instaurado sobre a presença/ausência dos deslocados nas produções artísticas que o fazer crítico assume novos contornos capazes de pôr em circulação o estabelecimento de molduras teóricas alicerçadas na traduzibilidade da movença dos saberes e sua capacidade permanente de reconfiguração. Um projeto de trabalho nessa direção oportuniza a releitura de noções como territórios linguísticos, atos performáticos de sujeitos históricos e geografias reais e imaginárias, a reorganização das fronteiras políticas e o remapeamento de territórios.

Com efeito, o mapa da travessia de Mwadia traz como marca principal a configuração territórios apátridas e vidas errantes, assinalando reencontros entre temporalidades e espacialidades várias. Isso, de acordo com Evelina Hoisel, contribui para sublinhar como:

A literatura submeteu-se a pressões teóricas, críticas e historiográficas, que pretendiam paralisar e neutralizar as errâncias, isto é, aprisionar os incessantes movimentos de sentido que se processam no corpo sígnico, bem como nas suas relações com as demais territorialidades linguísticas, o pensamento contemporâneo, traspassado pelas questões dos descentramentos, das desterritorializações, dos rizomas, dos processos históricos de revalorização, instaura um campo de saber que propicia a disseminação e proliferação dos trânsitos discursivos que tem caracterizado a literatura ao longo dos séculos (HOISEL, 2004, p.150).

O topus da colagem dos fragmentos da errância, dos deslocamentos e das partidas corta toda a estrutura da narrativa $O P S$, justapondo e tencionando a disjunção das memórias das personagens. Elas são provenientes de variadas geografias culturais. Destaquem-se, rapidamente, tais rastros identitários: 1) os religiosos portugueses D. Gonçalo da Silveira 


\section{Conexão Letras}

e Manoel Antunes; 2) o historiador americano Benjamim Southman - (rio arrancado da outra margem), 3) a socióloga brasileira Rosie Southman; 4) O escravo africano Nimi Nsundi; 5) o curandeiro Lázaro Vivo; 6) o comerciante português Antônio Caiado; 7) as goesas Dona Felipa e Luzmina Rodrigues e Dona Constança; 8) o indiano Jesustino; 9) o goês Chico Casuarino 10) Mwadia Malunga; 11) Zero Madzero, dentre outras.

Capturando as cenas dos passados não ditos, seguindo a linha de Bhabha (1998), a representação de corpos e linguagens estrangeiras no texto miacoutiano conjuga a perspectiva de que:

Cartografar pressupõe o delineamento de fronteiras, a demarcação dos limites entre territórios, sejam eles reais ou virtuais, simbólicos. O conceito de fronteira tem um sentido ambivalente, pois como linha de demarcação territorial, é o que separa, mas também o que permite contiguidades (HOISEL, 2004, p.150).

O delineamento das fronteiras como um dispositivo que, ambivalentemente, separa e agrega é tônica magma de $O P S$. Os seres de linguagem que habitam esse território de papel desbravam os interditos dos recortes temporais para (re)embaralhar paisagens textuais e atravessar o campo da história traumática do cerceamento de alteridades voláteis. Para fazê-las audíveis e visíveis, Mia Couto abre as janelas de sua literatura rumo à figuração de molduras narrativas assentadas na potencialidade das cenas dos trânsitos, travessias, migrações, passagens, trocas, diálogos e errâncias (HOISEL, 2004, p.151). A culminância desta prática intervalar desenha cartografias literárias e culturais que ressemantizam fronteiriçamente as múltiplas valências do imaginário das estéticas da margem.

Com base na possibilidade de reler os signos da diferença cultural, o escritor moçambicano tece alguns apontamentos sobre o papel desempenhado pelo intelectual africano e o manuseio que este faz dos discursos eurocêntricos que os inauguram discursivamente:

Os intelectuais africanos não têm que se envergonhar da sua apetência para a mestiçagem. Eles não necessitam de corresponder à imagem que os mitos europeus fizeram deles. Não carecem de artifícios nem de fectiches para serem africanos. Eles são africanos assim mesmo como são, urbanos de alma mista e mesclada, porque África tem pleno direito à modernidade, tem direito a assumir as mestiçagens que ela própria iniciou e que a tornam mais diversa e, por isso, mais rica ${ }^{10}$.

Alimentado desta seara temática, OPS torna manifesta as fissuras culturais de Mwadia. Ela experimenta "condições de fronteira e divisas" que as faz mover-se entre as dobras da memória do discurso logocêntrico para rasurá-lo, à medida que também abre a possibilidade de reescrever as histórias entrecruzadas dos atores sociais responsáveis por nomear construir os alicerces da cidade de Vila Longe. Nesse ínterim, há que se registrar que o retorno dessa personagem à sua terra natal deve ser encarado a partir da carga simbólica do testemunho do narrador:

Quem parte treme, quem regressa teme. Tem-se medo de se ser vencido pelo Tempo, medo de que a ausência tenha devorado as lembranças. A saudade é um morcego que falhou o fruto e mordeu a noite. À medida que se aproximava de sua vila, Mwadia ansiava recuperar o sentido de pertença a um lugar. Ela estava, a um tempo, receosa

10 Disponível em http://nunovrsantos.blogspot.com.br/2009/10/que-africa-escreve-o-escritor-africano.html. Acesso em 03 de março de 2013. 
e ansiosa. As vozes e olhares lhe iriam certamente devolver a perdida familiaridade. Nem ela adivinhava quanto os rostos de Vila Longe estavam vazios e inexpressivos, como se ela mesmo, regressando se mantivesse ausente (COUTO, 2006, p. 68).

O regresso de Mwadia à Vila Longe ressuscita os fantasmas que povoavam seu imaginário de ser que deambula pelos desertos da letra morta. Eles giram em torno da tradução dos nomes, mitos lendas e narrativas que, juntas, demarcam os limites fronteiriços do mapa de sua cartografia exterior e interior. Dito com outras palavras, o sentido de pertencimento não mais poderá ser adquirido com tanta facilidade, necessitando que seja respeitado o ritual de passagem, travessia e reconhecimento das novas mobilidades culturais que conformam as lembranças do lugar revisitado por Mwadia. Para ir mais direto no foco da questão, atentem-se às palavras de Mia Couto:

Consumimo-nos nesse momento em que, mesmo parados, partimos à procura do que não podemos ser. Estamos recriando o mundo, refazendo-o a jeito de um livro da nossa infância. Estamos brincando com o destino como o gato faz de conta que o novelo é um gato. No início, viajávamos porque líamos e escutávamos, deambulando em barcos de papel, em asas feitas de antigas vozes. Hoje viajamos para sermos escritos, para sermos palavras de um texto maior que é a nossa vida (COUTO, 2011, p. 75).

O tema da viagem/travessia tem sido constantemente explorado na literatura miacoutiana. Sem a pretensão de esgotar esse assunto, desloquemo-nos rapidamente pelo universo do terceiro capítulo de $O P S$, intitulado de Primeiro Manuscrito: o mar nu, escrito cuja ação narrativa desenvolve-se no ano de 1560. Aberta com duas epígrafes, esta parte do romance centra-se na narração das coordenadas para a realização da "primeira incursão católica no corte do Império de Monomopata. O missionário prometeu a Lisboa batizar o Imperador Negro. Levar o cristianismo para a África Inteira, que seria iluminada pela fé cristã"” (COUTO, 2006, p.51).

As personagens que viajam na Nossa Senhora da Ajuda são o jesuíta D. Gonçalo da Silveira, a estátua de Nossa Senhora, benzida pelo Papa (símbolo maior da peregrinação), Nimi Nsundi, Dona Felipa, os escravos africanos e a indiana Dia Kumari. A trajetória de cada uma dessas personagens revela o processo de figuração de vozes e corpos em trânsito, terminando por quebrar as fronteiras dos discursos que instalaram radares narrativos de uma leitura unilateral; da mística da oralidade e do essencialismo identitário, temas cambiantes na interpretação do ethos das margens. A esse respeito, põe-se à deriva a fala do narrador de $O P S$ :

A algazarrprofundezas do oceano. Era algo que, desde sempre, alvoroçava Gonçalo da Silveira: o modo como os negros gargalhavam, a facilidade da felicidade, a disponibilidade para a lascívia. Faltava aos selvagens não apenas um credo. Faltava-lhes moderação na alegria, tento no riso, parcimônia na paixão. A gargalhada é mulher, o riso é masculino. A primeira é própria dos bichos, a segunda é humana. Havia que humanizar os escravos. Afinal, para corrigir a gargalhada bem pa do porão torna-se mais intensa como se não brotasse do ventre do navio, mas das odia servir a gargalheira, essa coleira de ferro que prendia os escravos pelo peso. Era isso: a gargalhada pedia a gargalheira. (COUTO, 2006, p. 201).

Resgatando os interditos esmaecidos por trás dos processos de tradução cultural, a passagem transcrita acima evidencia o entrecruzamento dos diferentes usos da linguagem 
no contexto de vivência das personagens Gonçalo da Silveira e os negros africanos que viviam no porão da nau Nossa Senhora da Ajuda. Essa cena literária ganha mais densidade se aproximada da afirmação coutiana feita em Sete sapatos sujos (2011):

Minha mensagem é simples: mais do que uma geração tecnicamente capaz, nos necessitamos de uma geração capaz de questionar a técnica. Uma juventude capaz de repensar o país e o mundo. Mas do que gente preparada para dar respostas, necessitamos de capacidade para fazer perguntas. Moçambique não precisa apenas de caminhar. Necessita de descobrir o seu próprio caminho num tempo enevoado e num mundo sem rumo. A bússola dos outros não serve, o mapa dos outros não ajuda. Necessitamos inventar nossos próprios pontos cardeais. Interessa-nos um passado que não esteja carregado de preconceitos, interessa-nos um futuro que não nos venha desenhado como uma receita financeira (COUTO, 2011, p. 44).

Palco textual por onde transitam personagens orientais e ocidentais que dramatizam toda sorte de diferenças políticas, sociais, literárias, linguísticas, geográficas e históricas, essa passagem esmiúça as mutações das questões de identidade/alteridade africana, assim como traduz os pactos de visibilidade produzidos sobre o papel das margens na (re)configuração dos saberes híbridos.

Colocando em xeque as visões de África formuladas pelo pensamento ocidental, OSP exuma os resíduos do contato entre personagens territorializadas, desterrializadas, reterritializadas, nômades, errantes, intelectuais, contadores de história, feiticeiros, religiosos, escrivães, negros e estrangeiros. Por meio da cartografia das vidas em trânsito, o desenho das partidas e chegadas ao universo africano dá-se mediante a filtragem dos sentidos polivalentes que se esvaem pelas camadas textuais miacoutianas, pondo na agenda da prosa de ficção moçambicana a atmosfera cultural das migrâncias e dos hibridismos culturais.

Cotejada de tal ponto de vista, OSP reacende, de um lado, a chama do debate dos choques culturais entre os imaginários do tempo passado, presente e futuro. De outro lado, embaralham-se as cartas do jogo das memórias fraturadas pelo olhar castrador dos relatos ocidentais, lançando algumas pistas para revisitar os lugares onde se travaram as batalhas do direito de representar o outro nas malhas do saber tramado pelo ritmo do deslizar das tintas europeias sobre o papel fixado nos umbrais do imaginário africano.

\section{Considerações finais}

Em OSP, as cenas das fraturas da memória do contato entre nós, eles e os outros são revisitadas sem qualquer pretensão de endossar o já-dito, mas sim rasurar a lápide dos discursos estanques da nação como imagem homogênea, centrada e coesa. Pescando uma infinidade de sentidos das travessias, deslocamentos e migrações operadas no imaginário da tradução das paisagens ex-óticas, o romance enfocado perscruta as cercanias estéticas e políticas produzidas em torno das figurações das marcas e marcos da diferença cultural escamoteados pela tinta logocêntrica, a qual vilipendiou gestos, ritmos e cantos de variadas latitudes por onde o olhar e espírito europeu passaram para rasgar as franjas da voz e letra dos desistoricizados (BHABHA, 1998).

A leitura de $O P S$, sob essa égide crítica, permite conjugar esforços para operacionalizar a desestabilização da perspectiva binária sobre a qual se solidificara a retórica colonialista, rompendo com os olhares hiantes que celebram a hierarquização e subordinação do outro em detrimento da focalização do mesmo. Mais ainda, permite: 1) ultrapassar 
uma atitude que ratifica a literatura enaltecedora e transcendente, gestando uma visão de literatura inserida no contexto histórico e no espaço geopolítico; 2) mapear na ficção a ambigüidade que atravessa o perfil das personagens, sejam elas masculinas ou femininas; 3) investigar o aprisionamento do espaço colonial e pós-colonial pelo texto e pela teoria literária oriundos da metrópoles renascentistas ou modernas.

Ancorado na premissa de projetar o espaço da desmemória, OSP fornece ao estudioso de literatura a possibilidade de cartografar as fissuras, as contradições, as histórias heterogêneas, discrepantes de filões historicamente excluídos pelas lentes etnocêntricas. O grande desafio do crítico literário, hoje, é deixar aflorar as fraturas abertas das fronteiras de pátrias itinerantes, que constantemente se recombinam para produzir (geo)grafias de margens culturais ocultadas durante muito tempo.

Nesse sentido, a poética da travessia em Mia Couto constitui um espaço fecundo para rastrear os (des)encontros das vidas em trânsito. Com os pés fincados na tradução de cenas movediças, a escrita miacoutiana descosturar os nós discursivos feitos sobre as zonas de conflito, as interações, as assimilações recíprocas, as assimetrias e os conglomerados de diferenças culturais postos para baixo do tapete da narração da nação.

Essa última é vista, agora, como lugar incessante de deslocamentos, subversões, elementos de ruptura, pondo em xeque a lógica binária da empresa colonizadora. Resulta disso uma abertura estético-crítica para figurar as deformidades produzidas pelo olhar etnocêntrico, despindo-o dos graus de celebração de uma única interpretação para potencializar e desvelar lugares heterogêneos onde se dão os trânsitos ambíguos das práticas discursivas e políticas da(s) cultura(s).

Desse modo, pode-se chegar ao denominador comum de que a poética da travessia, em OPS, converge para a referencialidade dos seguintes pontos nevrálgicos:

a) Transitividade e transversalidade de saberes;

b) Expressão de uma inquietante responsabilidade do intelectual;

c) Análise das formas de recrudescimento das novas formas de marginalização;

d) A batalha sobre significação e valor;

e) Estudo dos movimentos migratórios e suas redes de trocas/assimetrias;

Desdobrados em sua magnitude poética, $O S P$ é um porto de passagem obrigatório para aqueles cuja paixão pela teoria, crítica e história e literatura comparada ocupam seu centro de interesse que se abre para dialogar com outras esferas do saber - tais como Antropologia, Filosofia, História Geografia, Literatura, Ecocrítica, dentre outros.

Como diria Eneida Maria de Souza (2007), Mia Couto tem sido um dos autores africanos cujos livros ocupam posição privilegiada na cabeceira da crítica brasileira. Ou ainda no dizer de Wander Melo Miranda (1994), em OSP, “a nação literária contém limiares de sentido que precisam ser atravessados, rasurados e traduzidos em seu processo de produção cultural". Por isso mesmo, a poética da travessia constitui elemento fundamental para perceber que $O S P$ potencializa o trânsito entre diferentes olhares que se abrem para dialogar entre si, sem sectarismos e exclusivismos estanques que obstaculizam a transumância teórica/estética.

Assim visto, $O S P$ conjuga a lição de que ler e analisar um texto literário é saber que ele esgarça a fronteira literária e convoca moldura de outros campos do saber, conforme pontua Eneida Souza. Destarte, para fechar com a prestimosa metáfora de Tania Carvalhal, OSP rastreia os encontros na travessia (1991), dando vazão aos modos de abertura ao Outro através da cartografia das cenas de vidas errantes. 
ABDALA JUNIOR, Benjamim. Fronteiras múltiplas, identidades plurais: um ensaio sobre mestiçagem e hibridismo cultural. São Paulo, Editora SENAC São Paulo, 2002. BERND, Zilá (org.). Escrituras híbridas: estudos em literatura comparada interamericana. Porto Alegre: Ed. Universidade/UFRGS, 1998.

. Identidades e estéticas compósitas. Porto Alegre Ed. Universidade/UFRGS, 1999. Dicionário de mobilidades culturais: percursos americanos. Porto Alegre; Literalis, 2010.

BHABHA, Homi. $O$ Local da Cultura. Trad. Myriam Ávila et al. Belo Horizonte: Ed. UFMG, 1998.

CALVINO, Italo. Seis propostas para o próximo milênio. Trad. Ivo Barroso, São Paulo, Companhia das Letras, 1990.

COMPAGNON, Antoine. Os cinco paradoxos da modernidade. Belo Horizonte, Editora da UFMG, 2010.

As cidades invisíveis. Companhia das Letras, São Paulo, 2004.

CARVALHAL, Tania Franco. O próprio e o alheio: ensaios de literatura comparada. RS, Editora UNISINOS, 2003.

COUTO, Mia. O outro pé da sereia. São Paulo: Companhia das Letras, 2006.

. E se Obama fosse africano?: e outras intervenções. São Paulo: Companhia das Letras, 2011.

CURY, M. Z. F. (Org.); ÁVILA, M. (Org.); Ravetti, G. (Org.). Topografias da cultura: representação, espaço e memória. 1. ed. Belo Horizonte: Editora UFMG, 2009.

FONSECA, Maria Nazareth Soares e CURY, Maria Zilda Ferreira. Mia Couto: espaços ficcionais. Belo Horizonte: Autêntica, 2008.

. Identidades andarilhas passeiam pela literatura. In. GALVES, Charlotte; GARMES, Helder; RIBEIRO, Fernando Rosa. África-Brasil: caminhos da língua portuguesa. Campinas, Editora da Unicamp, 2009.

GLISSANT, Édouard. Introdução à poética da diversidade. Editora da UFJF, Juiz de Fora, 2005.

. Poética da relação. Sextante editora, Portugal, 2011.

KRISTEVA, Julia. Estrangeiros para nós mesmos. Trad. Maria Carlota Carvalho Gomes. Rio de Janeiro: Rocco, 1994.

LEITE, Ana Mafalda. Oralidades e escritas nas literaturas africanas. Lisboa: Ed. Colibri, 1998.

. Literaturas africanas e formulações pós-coloniais. Lisboa: Colibri, 2012.

MIRANDA, Wander Melo. Nações literárias. Revista Brasileira de Literatura Comparada, São Paulo, n. 2, p. 31-38, maio 1994.

SAID, Edward W. Cultura e imperialismo. São Paulo: Companhia das Letras, 1995.

. Orientalismo: o Oriente como invenção do Ocidente. São Paulo: Companhia das Letras, 2001.

SANTIAGO, Silviano. O entre-lugar do discurso latino-americano. In: Uma literatura nos trópicos. Ensaios sobre dependência cultural. São Paulo: Editora Perspectiva, 1978, p. 11-28.

SECCO, Camen Lucia. A magia das letras africanas. Rio de Janeiro: ABE GRAPH, 2003. SCHMIDT, R. T. (Org.); MASINA, L. S. S. (Org.); BITTENCOURT, G. N. S. (Org.). Geografias Literárias e Culturais: espaços/temporalidades. Porto Alegre: Editora da UFRGS, 2004. 172 p. 